\title{
ОСОБЛИВОСТІ КРИМІНОЛОГІЧНОї ДІЯЛЬНОСТІ СУДОВО-ЕКСПЕРТНИХ УСТАНОВ УКРАЇНИ ЩОДО ПРАВОВОГО ВИХОВАННЯ НАСЕЛЕННЯ
}

\author{
ФІЛІПЕНКО Наталія Свгенівна - кандидат юридичних наук, доцент (доцент \\ кафедри права Національного аерокосмічного університету ім. М. Є. Жуковського \\ «Харківський авіаційний інститут») \\ Orcid:https://orcid.org/0000-0001-9469-3650 \\ УДК 343.9 \\ DOI 10.32782/NP.2020.4.11
}

\begin{abstract}
В статье исследуется проблема правового воспитания населения как одного из направления криминологической деятельности экспертных учреждений в Украине. Несмотря на главную задачу экспертнъх учреждений в процессе проведения экспертиз, отмечается на самостоятельности и важности воспитательного направления деятельности эксперта. Установлено отсутствие на национальном уровне системной нормативной базв по привлечению экспертных уиреждений в прочесс правового воспитания населения по вопросам предупреждения преступности. Проанализированы нормативнъе акты иеентральных органов власти и органов местного самоуправления относительно полномочий экспертнъх учреждений в сбере повътения правового образования населения и правовой пропагандъ.

Ключевъе слова: эксперт, экспертная пробилактика, правовое воспитание, преступность, девиктимизачия.
\end{abstract}

\section{Постановка проблеми}

Кримінологічна діяльність експертних установ не обмежується процесуальною діяльністю експерта. Ще у XVIII ст. Ч. Беккаріа зазначав, що найбільш правильним, хоча й найбільш складним засобом попередження злочинів є виховання [1, с. 241]. На сьогодні ідея важливості здійснення виховного впливу як дієвого засобу протидії злочинності на загальносоціальному, груповому й індивідуальному рівні $є$ за- гальноприйнятною та використовується кримінологами як під час розробки теорій протидії злочинності в цілому, так і для обгрунтування пропозицій щодо протидії окремим видам злочинів [2, с. 251]. Так, Г. С. Саркісов, досліджуючи проблему соціальної системи попередження злочинності, зазначав, «що усунення загальних причин злочинів і умов, які сприяли їх скоєнню, є основним напрямом соціальної системи попередження злочинів, але разом 3 тим, ця система повинна вирішувати і деякі «підлеглі завдання». До останніх він відносить виправлення та перевиховання осіб, що здійснили злочини; викорінення із свідомості людей пережитків минулого, антисуспільних поглядів, прагнень, спонукань збочених потреб тощо [3, с. 136].

Водночас значним недоліком сучасної правовиховної діяльності в системі протидії злочинності $\epsilon$ відсутність збалансованої державної політики в цьому питанні. Становлення України як демократичної, правової держави, формування засад громадянського суспільства вимагають підвищення рівня правової культури населення. Потребують вирішення на державному рівні питання подальшого розвитку правосвідомості населення, подолання правового нігілізму, задоволення потреб громадян у одержанні знань про право. Це може бути забезпечено, насамперед, шляхом удосконалення правової освіти населення, в тому числі за допомогою правовиховної діяльності експертних установ. 


\section{Аналіз публікацій, у яких започатковано розв'язання цієі проблеми}

Питанням розробки теорії судової експертології та експертної профілактики були присвячені роботи багатьох вчених радянської доби, сучасних вітчизняних науковців та фахівців закордонних шкіл. Серед них: Т. В. Авер'янова, I. А. Алiєв, Ф. Г. Амінєв, М. І. Бажанов, B. С. Батиргарєєва, Р. С. Белкін, А. Ф. Волобуєв, В. В. Голіна, Д. П. Гуріна, Ф. Е. Давудов, I. М. Даньшин, O. М. Джужа, В. А. Журавель, А. В. Іщенко, В. Ю. Квашис, О. М. Клюєв, В. П. Колмаков, В. Г. Аукашевич, В. В. Аук'яненко, Г. А. Матусовський, Г. М. Міньковський, О. Г. Міхайлянц, П. П. Михайленко, О. М. Моїсєєв, Е. Б. Сімакова-Ефремян, О. П. Снігерьов, І. Я. Фрідман, В. Ю. Шепітько, О. В. Шеслер, В. М. Шерстюк, М. Г. Щербаковський, О. П. Угровецький, М. П. Яблоков та інші. Труди названих учених, беззаперечно, слугують основою нашого дослідження, але сьогодення потребує подальшого теоретичного аналізу та розкриття окресленої проблематики. Адже сформульовані у цих трудах норми і постулати потребують не лише вдосконалення та уточнення, а й формування, на підставі концептуальних змін чинного законодавства, нового погляду на особливості кримінологічної діяльності експертних установ.

Мета дослідження: дослідити правові засади кримінологічної діяльності експертних установ у сфері правового виховання та запропонувати шляхи їі вдосконалення.

Завдання дослідження обумовлене метою роботи та полягає в необхідності юридичного аналізу нормативної бази чинного законодавства щодо профілактичної діяльності експертних установ 3 правового виховання населення, повноважень експерта з зазначеного напрямку та способів їх реалізації.

\section{Основний текст}

Слiд зазначити, що значна частина заходів, які розробляються на національному та регіональному рівнях у питаннях правової освіти громадян [4], грунтуються на Указі Президента № 992/2001 від 18 жовтня 2001 року «Про Національну програму правової освіти населення», якому вже виповнилося 19 років і який приймався в зовсім інших умовах розвитку держави [5]. Вбачається, що більшість запропонованих напрямків із забезпечення програми залишаються нереалізованими, зокрема, такі як:

- здійснення місцевими органами виконавчої влади, органами місцевого самоврядування в межах своєї компетенції заходів до розширення мережі спеціалізованих навчальних закладів, бібліотек, збільшення кількості друкованих та аудіовізуальних засобів масової інформації правового спрямування;

- систематичного інформування державними засобами масової інформації населення про національне законодавство, діяльність органів законодавчої, виконавчої, судової влади, а також про стан правопорядку, боротьбу з правопорушеннями, особливо серед неповнолітніх, профілактику їх вчинення тощо;

- створення загальних i навчальних телевізійних та радіомовних каналів, а також запровадження сторінки, рубрики та інших популярних форм надання правової інформації для подальшого вдосконалення правової освіти населення в межах державного замовлення;

- проведення відповідної правоосвітньої та правовиховної діяльності державними закладами, підприємствами та організаціями культури;

- створення лекторіїв, кінолекторіїв, проведення виставок друкованої продукції правового спрямування, зустрічей 3 фахівцями-юристами, читацьких конференцій та інших заходів за участю органів виконавчої влади, відповідних управлінь юстиції, навчальних закладів і наукових установ на громадських або договірних засадах. 


\section{Кримінальне право, кримінальний процес та криміналістика}

До того ж, залишаються поза увагою такі актуальні питання українського сьогодення, як тероризм, сепаратизм, військові загрози тощо. За відсутності загальнонаціональних актуальних програм правовиховної діяльності в системі протидії злочинності, посилена увага зазначеному питанню повинна бути приділена на регіональному рівні. Так, силами обласних державних адміністрацій розроблені Програму правової освіти населення відповідних областейна наступні 3-4 роки, зокрема Сумської, Полтавської, Харківської, Івано-Франківської, Волинської, у яких не останне місце займають заходи 3 проведення систематичного інформування населення в засобах масової інформації, iз застосуванням інших форм і методів інформування про державну правову політику, стан законності та правопорядку в області, забезпечення прав, свобод та інтересів громадян, про зміни в законодавстві, діяльність органів законодавчої, виконавчої, судової влади, органів місцевого самоврядування, а також щодо проведення профілактики правопорушень [4; $6 ; 7 ; 8]$.

На підставі аналізу вітчизняного і зарубіжного досвіду реалізації правовиховної діяльності всі зазначені заходи традиційно можна розділити за наступними критеріями: за об'єктами правовиховного впливу, за змістом, за способом та за формами реалізації.

За об’єктами правовиховного впливу можна виділити такі види правовиховних заходів експертних установ у системі протидії злочинності: 1) спрямовані на населення країни, регіону в цілому; 2) спрямовані на певні групи населення. Виділення зазначених груп населення може здійснюватися за ознакою віку, професії або фахової належності, віктимологічної уразливості.

Заходи першої групи спрямування мають загальний характер і пов'язані 3 інформуванням населення щодо положень чинного законодавства та змін до нього, інформування щодо криміногенних ризиків та шляхів їх уникнення, здійснення правовиховного впливу 3 метою усунен- ня причин та умов злочинності. У той же час друга група зазначених заходів спрямовується на конкретні групи населення, що дозволяє максимально врахувати їх соціально-психологічні й культурні особливості, які можуть вплинути на процес здійснення та кінцевий результат виховного впливу, зокрема вік, фах, професійну діяльність, схильність до правопорушень, віктимологічних груп.

Особливе значення для діяльності експертних установ має напрямок правовиховної роботи, пов'язаний із підвищенням кваліфікації працівників правоохоронних органів. Так, п. 2.13 заходів Регіональної програми забезпечення публічної безпеки і порядку та протидії злочинності на території Харківської області на 20202022 роки [9] передбачає проведення в установленому законодавством порядку навчання для працівників підрозділів поліції, служби пробації та посадових осіб органів місцевого самоврядування 3 питань забезпечення спільного контролю за правомірністю поведінки осіб, які звільняються 3 місць позбавлення волі, здійснення заходів щодо їх ресоціалізації. Актуальним у таких випадках 6 саме залучення експертних служб з метою посилення профілактичної діяльності підрозділами ОВС. Так, у Наказі МВС РФ № 261 від 1.06.1993 р. «Про підвищення ефективності експертно-криміналістичного забезпечення діяльності органів внутрішніх справ Російської Федерації» у розділі 4 розкривалися пункти, за якими повинна здійснюватися профілактична робота, зокрема: «визначення можливих способів скоєння злочинів з урахуванням використання злочинцями технічних засобів та конструктивних недоліків місць зберігання матеріальних цінностей та грошових коштів; участь у навчанні посадових осіб відповідних міністерств і відомств способам розпізнавання фактів злочинних проявів, пов'язаних з підробкою документів, цінних паперів, злому пломб, запірних приладів і т.п....» [10, с. 162].

Особливої уваги заслуговує також віктимологічна профілактика населення або його окремих груп. Концепція вікти- 
мологічної профілактики базується на інформуванні правоохоронними органами населення про сучасні форми прояву злочинності та можливості ефективного попередження злочинів; забезпечення захисту потенційних жертв; створення умов для активного співробітництва населення й поліції. Так, підрозділ V Превентивних заходів щодо протидії правопорушенням проти власності у п. 5.2 передбачає організацію інформування населення, у тому числі через засоби масової інформації, про необхідність вжиття заходів щодо посилення охорони власного майна, встановлення охоронної сигналізації, домофонів, укріплення вхідних дверей, встановлення кодових замків на під’їздах житлових будинків тощо з метою попередження квартирних крадіжок та інших крадіжок майна $з$ житла громадян [9].

Планувати слід й інші форми профілактичної роботи. В експертній установі повинні бути узгоджені плани надання допомоги окремим організаціям, установам, відомствам у роботі щодо виявлення різних недоліків, упущень та інших обставин, що сприяють різним правопорушенням, тексти лекцій з питань профілактики (як для визначених категорій посадових осіб, так і для населення), плани проведення цих лекцій.

За змістом можна виділити такі види правовиховних заходів експертних установ у сфері протидії злочинності:

1) інформаційно-просвітницькі (проведення інформаційно-роз'яснювальних заходів щодо різних аспектів протидії злочинності);

2) профілактичні (проведення практичних тренувань, консультацій щодо питань забезпечення публічної безпеки, уникнення криміногенних ризиків, недопущення вчинення правопорушень);

3) агітаційні.

Беззаперечно, необхідною в такого роду заходах є участь експерта, в тому числі пов'язаних зі здійсненням контролю за обігом небезпечних предметів. Так п. 3.4 вже згаданої регіональної програми передбачає організацію проведення контрольних перевірок та інших форм запо- біжної роботи щодо забезпечення належного обліку та безпеки зберігання зброї, боєприпасів, вибухових речовин, інших засобів ураження, що перебувають у розпорядженні підприємств, організацій та установ. Участь експерта щодо зазначеної профілактичної діяльності є не тільки бажаною, але й обов'язковою [9].

За способами реалізації можна виділити такі види правовиховних заходів: участь у заходах 3 використанням 3MI, мережі Інтернет, залучення й використання налагоджених відносин взаємодії 3 державними та недержавними суб'єктами протидії злочинності, використання взаємодії 3 освітніми установами, закладами охорони здоров'я, громадськими організаціями, міжнародними установами тощо. Так, План заходів на 2019-2020 роки з реалізації Стратегії державної політики щодо наркотиків на період до 2020 року, затверджений розпорядженням КМ України № 56-р від 6 лютого 2019 р., передбачає залучення експертів у галузі психічних розладів внаслідок вживання психоактивних речовин 3 метою сприяння висвітленню у засобах масової інформації відомостей про небезпеки, пов'язані із вживанням психоактивних речовин, а також про методи профілактики психічних розладів, пов'язаних з таким вживанням. Індикатором досягнення зазначеної мети визначено розміщення публікацій у засобах масової інформації, проведення тематичних зустрічей та здійснення інших форм інформування населення про небезпеки, пов'язані із вживанням психоактивних речовин, а також про методи профілактики психічних розладів, пов'язаних 3 таким вживанням [11].

За бормами реалізації можна виділити такі види правовиховних заходів експертних установ у сфері протидії злочинності:

- проведення інформаційних кампаній, акцій;

- проведення конференцій, круглих столів та обговорень;

- проведення практичного навчання, тренінгів;

- випуск друкованих й цифрових інформаційних матеріалів. 


\section{Кримінальне право, кримінальний процес та криміналістика}

Відповідно до ст. 8 закону України «Про судову експертизу» для розгляду найважливіших питань розвитку судової експертизи, що мають міжвідомчий характер, при Міністерстві юстиції України створюється Координаційна рада 3 проблем судової експертизи, яка діє відповідно до Положення [12] про неї, що затверджується Кабінетом Міністрів України. Згідно i3 зазначеним Положенням Науковоконсультативна та методична рада з проблем судової експертизи (НКМР) бере участь в організації та підготовці «круглих столів», семінарів, науково-практичних конференцій $з$ актуальних проблем судової експертизи, організовує обмін досвідом; сприяння підвищенню кваліфікації наукових і експертних кадрів судово-експертних установ; бере участь у розробці програм підготовки експертних кадрів та розгляді пропозицій до планів стажування працівників судово-експертних установ Мін'юсту; сприяе міжнародному співробітництву в галузі криміналістики й судової експертизи; надає пропозиції судово-експертним установам з удосконалення науково-методичного, організаційно-управлінського та інформаційного забезпечення судово-експертної діяльності.

До основних повноважень НКМР відносять підготовку пропозицій до програм навчання судових експертів та планів стажування працівників судово-експертних установ; розгляд спірних питань експертної практики, непідтверджених повторних експертиз та обговорення інших питань $з$ удосконалення та розвитку судової експертизи.

Згідно з уже згадуваним планом заходів на 2019-2020 роки з реалізації Стратегії державної політики щодо наркотиків на період до 2020 року заплановано проведення наукових досліджень проблем, пов'язаних 3 психоактивними речовинами, яке передбачає розроблення за активної участі судово-психіатричних експертів алгоритму застосування примусових заходів медичного характеру та альтернативного позбавленню волі лікування осіб 3 психічними та поведінковими розладами внаслідок вживання психоактивних речовин.

Важливим залишається i напрямок інформаційної пропаганди, шляхом видання відповідних друкованих та інформаційних матеріалів. Так, на Міністерство юстиції України покладається обов'язок видання міжвідомчого науково-методичного збірника «Криміналістика та судова експертиза», у якому приділяється увага i профілактичній діяльності експертних установ.

\section{Висновки}

Таким чином,слід визнати, що, незважаючи на головне завдання експертних установ у процесі проведення експертиз, виховний напрямок діяльності експерта є самостійною та важливою складовою кримінологічної діяльності експертних установ. Проведення правовиховного заходу iз залученням експерта потребує ретельної підготовки, визначення мети та його змісту, особи, на яких спрямовано правовиховний вплив, а за необхідності - співвиконавці заходу, конкретні способи й форми його реалізації, очікувані результати та індикатори досягнення поставленої мети.

Сучасна нормативна база щодо правового виховання населення потребує удосконалення 3 врахуванням особливостей злочинності на нинішньому етапі розвитку нашої держави. До того ж, для підвищення ефективності правовиховних заходів експертних установ у сфері протидії злочинності обов'язковим є одночасне поєднання декількох форм їх реалізації, зокрема, за результати конференцій, круглих столів, обговорень можуть публікуватися друковані матеріали, повідомлення в Інтернет тощо.

\section{Лiтература}

1. Беккариа Ч. О преступлениях и наказаниях. М., 1995. 304 с.

2. Шайтуро О. П. Органи місцевого самоврядування у сфері протидії злочинності: монографія. Харків : Панов А. М., 2019. 409 c. 
3. Саркисов Г. С. Социальная система предупреждения преступности. Ереван, 1975. 159 с.

4. Рішення Івано-Франківської обласної ради № 818-20/2018 від 02.03.2018 «Про Програму правової освіти населення області на 20182022 роки». URL: https://orada.if.ua/ decision $/ \%$ D0\%B F\%D 1\%80\%D0\%BE-\%D0\% B F $\%$ D $1 \% 80 \%$ D0\% BE $\%$ D0\% B $3 \%$ D 1\%80\%D 0\% B 0\% D0\% BC\% D 1\%83-\% D0\% B F\% D $1 \% 8$ $0 \% \mathrm{D} 0 \% \mathrm{~B} 0 \% \mathrm{D} 0 \% \mathrm{~B} 2 \% \mathrm{D} 0 \% \mathrm{BE} \% \mathrm{D} 0 \% \mathrm{~B} 2 \% \mathrm{D} 0$ $\%$ BE $\%$ D $1 \% 97-\% \mathrm{D} 0 \% \mathrm{BE} \% \mathrm{D} 1 \% 81 \% \mathrm{D} 0 \% \mathrm{~B} 2 \%-$ D $1 \% 96 \% \mathrm{D} 1 \% 82 \% \mathrm{D} 0 \% \mathrm{~B} 8-\% \mathrm{D} 0 \% \mathrm{BD} \% \mathrm{D} 0 \% \mathrm{~B}$ 0\%D $1 \% 81 \% \mathrm{D} 0 \% \mathrm{~B} 5 \% \mathrm{D} 0 \% \mathrm{BB} \% \mathrm{D} 0 \% \mathrm{~B} 5 \% \mathrm{D} 0 \%$ BD/ (дата звернення: 15.11.2020).

5. Указ Президента України № 992/2001 від 18.10.2001 «Про Національну програму правової освіти населення». URL: https://minjust.gov.ua/m/ukaz-prezidentaukraini-vid-18-jovtnya-2001 roku-9922001pro-natsionalnu-programu-pravovoi-osvitinaselennya (дата звернення: 15.11.2020).

6. Рішення Сумської обласної ради від 28.04.2017 «Про обласну програму правової освіти населення області на 2017-2020 роки». URL: https:// sorada.gov.ua/dokumenty-oblrady/ 7 sklykannja/category/159-13-session. html?download $=5476 \% 3 \mathrm{~A} 13-$ session -30 (дата звернення: 15.11.2020).

7. Рішення Волинської обласної ради № 228 від 17.04.2018 «Про обласну програму правової освіти населення області на 2018-2022 роки». URL: https://voladm.gov. $\mathrm{ua} / \mathrm{new} /$ nacionalna-programa-pravovoyiosviti-naselennya-v-oblasti-zatverdzhenoplan-zahodiv/ (дата звернення: 15.11.2020).

8. Рішення Полтавської обласної ради № 91 від 29.04.2016 «Про обласну програму правової освіти населення області на 2016 - 2020 роки». URL: https://oblrada-pl. gov.ua/ses/7/31/1293.pdf (дата звернення: 15.11.2020).

9. Про затвердження Регіональної програми забезпечення публічної безпеки і порядку та протидії злочинності на території Харківської області на 2020-202 роки. URL: http://oblrada.kharkov.ua/ua/ public-information/oblasni-programi/323rehionalna-prohrama-zabezpechennia- publichnoi-bezpeky-i-poriadku-ta-protydiizlochynnosti-na-terytorii-kharkivskoioblasti-na-2018-2019-roky (дата звернення: 15.11.2020).

10. Кисилевич И. В. Экспертнопрофилактическая деятельность на современном этапе // Вестник экономической безопасности. No 2. 2020. С. 161-164.

11. Розпорядженням КМ України № 56-р від 6.02.2019 «Про затвердження плану заходів на 2019-2020 роки з реалізації Стратегії державної політики щодо наркотиків на період до 2020 року». URL: https://zakon.rada.gov.ua/laws/show/562019-\%D1\%80\#Text (дата звернення: 15.11.2020).

12. Наказ Міністерства юстиції України № 470/5 від 27.03.2012 «Про затвердження Положення про науково-консультативну та методичну раду з проблем судової експертизи при Міністерстві юстиції України». URL: https:/zakon.rada.gov.ua/ laws/show/z0460-12\#n16 (дата звернення: 15.11.2020).

\section{PREVENTIVE ACTIVITY OF EXPERT INSTITUTIONS OF UKRAINE ON LEGAL EDUCATION OF THE POPULATION}

The article examines the problem of legal education of the population as one of the areas of criminological activities of expert institutions in Ukraine. Despite the main task of expert institutions in the process of conducting examinations, the independence and importance of the educational direction of the expert is emphasized. It is noted that at the national level there is no systemic regulatory framework for the decision of expert institutions in the process of legal education of the population on crime prevention. The normative acts of central authorities and local self-government bodies on the powers of expert institutions in the field of improving the legal education of the population and legal propaganda are analyzed. Identified deficiencies and lack in some cases due to the realities of present national programs for legal education of the population. The distribution of legal education activities by objects 


\section{Кримінальне право, кримінальний процес та криміналістика}

у статті досліджуться проблема правового виховання населення як одного з напрямків кримінологічної діяльності експертних установ в Украйні. Незважаючи на головне завдання експертних установ у прочесі проведення експертиз, наголошується на самостійності та важливості виховного напрямку діяльності експерта. Зазначається відсутність на національному рівні системної нормативної бази щодо залучення експертних установ у процес правового виховання населення з питань попередження злочинності. Проаналізовано нормативні акти центральних органів влади та органів місцевого самоврядування щодо повноважень експертних установ у сфері підвищення правової освіти населення та правовоі пропаганди. Виявлені недоліки та відсутність в окремих випадках зв'язку з реаліями съогодення начіональних програм правової освіти населення. Проведено розподіл правовиховних заходів за об'єктами правовиховного впливу, за змістом, за способом та за формами реалізаизї. Особливої уваги приділено правовиховним заходам із залучення експерта до навчання працівників правоохоронних органів та проблемам віктимологічної профбілактики населення. Доведено, що проведення правовиховних заходів за участю експерта потребують ретельної підготовки, визначення мети та їх змісту, осіб, на яких спрямовано заходи правовиховного впливу, а за необхідності - співвиконавиів заходу, конкретні способи й борми його реалізацї, очікувані результати та індикатори досягнення поставленої мети. Запропоновані шляхи вдосконалення нормативної бази з питань залучення експертних установ щодо заходів з правового виховання населення.

Ключові слова: експерт, експертна профілактика, правове виховання, злочинність, девіктимізаиія. of legal education, by content, by method and by forms of implementation. Particular attention is paid to legal education measures to involve an expert in the training of law enforcement officers and the problems of victim prevention. It is proved that conducting legal education activities with the participation of an expert requires careful preparation, definition of the purpose and its content, persons targeted by legal education measures, and if necessary - co-executors of the event, specific ways and forms of its implementation, expected results and indicators. Ways to improve the regulatory framework for the involvement of expert institutions on measures for legal education of the population are proposed.

Keywords: expert, expert prevention, legal education, crime, devictimization. 